\title{
Influence of energy drinks on the risk of overweight and obesity among high school students from Southern Poland
}

\author{
Ewa Błaszczyk-Bębenek, \\ Paweł Jagielski, \\ Małgorzata Schlegel-Zawadzka \\ Human Nutrition Department, Faculty of \\ Health Sciences, Jagiellonian University \\ Medical College, 20 Grzegórzecka str. \\ 31-531 Krakow, Poland \\ Received: $20^{\text {th }}$ September 2016. \\ Corresponding author: \\ Ewa Błaszczyk-Bebenek \\ Human Nutrition Department, Faculty of Health \\ Sciences, Jagiellonian University Medical College \\ Sciences, Jagiellonian Univers ity Medical College \\ ewa.blaszczyk@uj.edu.p
}

\begin{abstract}
Studies available confirm the link between sugary beverages, included energy drinks, and the risk of overweight and obesity among different age groups. The aim of the study was to evaluate the influence of energy drinks on the overweight and obesity development among high school students from urban and rural environments. The study was conducted among high school students from Southern region of Poland. The survey included 518 students, aged 16 to 20 years. Survey instruments were anthropometric measurements of body height, weight and waist and hips measurements. Such indicators as BMI, WHtR and WHR were calculated and interpreted according to the current methodology. The collected data were analysed using statistical program Statistica 10.0 PL. Based on the group included in the research it can be said that the place of residence and gender affect statistically significantly the consumption of energy drinks. The frequency and amount of energy drinks consumption statistically significantly affect selected anthropometric parameters of the study population. Based on the study it can be concluded that energy drinks can cause excessive weight gain in young people.
\end{abstract}

Keywords: youth, energy drinks, overweight, obesity, nutrition behaviour

\section{INTRODUCTION}

Energy drinks are supposed to help in stressful situations, endure fatigue, move the drowsiness, improve the efficiency of the mind, sharpen cognitive functions, concentration and reduce weight $[1,2,3]$ The prevalence of energy drinks consumption amounted $86 \%$ among adolescents aged 10-18 years, residing in European countries. According to the data, the biggest prevalence of energy drinks consumption was in Belgium (85\%) the lowest in Greece $(48 \%)$. According to the same report there was $73 \%$ prevalence of consumption of energy drinks among Polish adolescents. Energy drinks were more common in the group aged $15-18$ years (73\%) than in the younger age group $10-14$ years (55\%). Boys more often than girls consumed energy drinks (74\% vs. $63 \%)[4]$.

The sugar content in energy drinks available on the Polish market is from $11.1 \mathrm{~g}$ to $16.8 \mathrm{~g} / 100$ $\mathrm{ml}$ of product. The information on their packaging even in $48 \%$ was different from the data obtained using high performance liquid chromatography. The highest level of fructose from 12 samples of beverages was $5.67 \mathrm{~g} / 100 \mathrm{ml}$, glucose $7.96 \mathrm{~g} / 100$ $\mathrm{ml}$ and sucrose $7.35 \mathrm{~g} / 100 \mathrm{ml}$ in product. For adult human, carbohydrates from the one of very popular energy drink cans, met the energy requirements for carbohydrates over 76\% [5]. The increase in the supply of calories along with the consumption of energy drinks becomes important, because of their possible impact on the obesity epidemic. Additional calories may increase blood pressure, blood glucose, body mass index (BMI), cause calcium deficiency, dental problems, depression and low self-esteem [3]. Beverages containing a large amount of sucrose in composition also have a high glycaemic index. High glycaemic level in the blood, leads to a reduction of the sensitivity of cells to insulin. As a result, distorted signal is transmitted to the centre of hunger and satiety, the satiety feeling is reduced, and body is still looking for products that provide it with energy [6].

Due to the fact that the sugary soft drinks can contribute to the development of overweight and obesity more people including teens control their quantity. Unfortunately, energy drinks may surreptitiously supplement the gap, because at this age group are consumed in relatively large quantities, despite the fact that they are sweetened like the other sugar beverages $[7,8]$.

\section{OBJECTIVE}

The aim of the study was to evaluate the influence of energy drinks on the overweight and obesity development among high school students from urban and rural environments.

\section{METHOD}

The survey was conducted during 2014-2015 year among high school students from Southern 
Poland. Each person filled in an anonymous questionnaire on frequency of selected products consumption and questionnaire about nutritional habits of drinking energy drinks. Anthropometric measurements (weight, height, waist and hips) were also performed among the respondents. Such indicators as BMI (Body Mass Index), WHtR (Waist to Height Ratio) and WHR (Waist to Hip Ratio) were calculated and interpreted. Body Mass Index - BMI was calculated by using the formula: weight [kg]/ body height $\left[\mathrm{m}^{2}\right]$. Interpretation of this indicator for the study group of young people has been made on representative population of children and young people of school age centile charts of body height, weight and BMI, developed in Polish research OLAF [9].Indicator waist - growth (WHtR) was calculated as follows: waist circumference $[\mathrm{cm}] /$ height $[\mathrm{cm}]$. For the interpretation of the indicator WHtR has been used constant pointer for both genders, equal to 0.5. Last used indicator was Waist to Hip Ratio (WHR) which was calculated as waist circumference $[\mathrm{cm}]$ divided by hip circumference $[\mathrm{cm}]$. The interpretation of this indicator was based on the value of the points, according to the WHO to assess the metabolic syndrome, in men $\geq 0$.9and women $\geq 0.85$ respectively $[10]$.

Differences between distinguished groups, because of the place of residence and gender were analysed using an independent-sample nonparametric Mann-Whitney U-test and to strength measurement of the association Spearman rank correlation coefficient was calculated. The results with $p$-values $\leq 0.05$ were considered as statistically significant. All statistical analyses were performed using Satistica PL 10.0.

\section{RESULTS}

Five hundred eighteen high school students, from seven schools of two Polish provinces completed the study. $241 \quad(46.63 \%)$ high school students from Podkarpackie voivodshiprepresentingrural region took a part in the study as well as $277(53.47 \%)$ participants were from Malopolska voivodship (urban region). The average age of study participants was $17.15 \pm 0.60$ years, the youngest participant in the study was 16 and the oldest 19.5 year old. The study involved, more girls ( 263 girls $-51.16 \%$ ) than boys ( 253 boys $48.84 \%)$, however it was no statistical differences $(p=0.8200)$. The assessment of nutritional status of study groups indicated statistically significant differences. High school students from rural areas significantly more often had higher waist, hips measurements and the rate of WHtR. Study groups of girls and boys were significantly differing in terms of estimated parameters of nutritional status except the WHR ratio. The exact characteristics are presented in Table 1.

Although, the body mass index - BMI for overall respondents indicated mostly normal weight, accurate analysis showed some irregularities. More students from the rural areas $(73.86 \%)$ had normal body mass than of the urban areas (72.20\%). Proper body weight was more often performed also in boy group $(74.31 \%)$ than girls $(71.70 \%)$. BMI in the interpretation of centile charts from the Polish research project named OLAF, pointed out obesity in $6.76 \%$ of respondents. Accurate data illustrated Figure 1.

Next to the assessment of nutritional status were also made attempts to assess the consumption of energy drinks in the study groups of adolescents. Among high school students from Southern Poland, energy drinks tried $89.19 \%$ of the youth. Never drank such type of beverages $8.49 \%$ of the surveyed students. Energy drinks were the most commonly consumed 1 to 3 times a month $(21.04 \%)$ in the study population. Every day, this type of drink, drank only $0.97 \%$ of the total study group. Daily, energy drink drank more young people from urban areas $(1.08 \%)$ than in rural areas $(0.83 \%)$. The place of residence differed significantly frequency of energy drinks consumption $(p=0.0120)$. Boys significantly more likely tried an energy drink than girls $(p=0.0037)$. Never drank an energy drink $26.88 \%$ boys and $36.98 \%$ girls up from the Southern Poland.

Table 1. Evaluation of the nutritional status of the study group by gender and place of residence

\begin{tabular}{|c|c|c|c|c|c|}
\hline \multirow[b]{2}{*}{ Parameter } & \multicolumn{5}{|c|}{ Mean \pm standard deviation $(X \pm S D)$} \\
\hline & $\begin{array}{c}\text { Total } \\
\mathrm{N}=\mathbf{5 1 8}\end{array}$ & $\begin{array}{l}\text { Rural region } \\
\qquad \mathbf{N}=\mathbf{2 4 1}\end{array}$ & $\begin{array}{l}\text { Urban region } \\
\qquad N=\mathbf{2 7 7}\end{array}$ & $\begin{array}{c}\text { Boys } \\
\mathrm{N}=\mathbf{2 5 3}\end{array}$ & $\begin{array}{c}\text { Girls } \\
N=265\end{array}$ \\
\hline Age [years] & $17.5 \pm 0.60$ & $17.29 \pm 0.64 *$ & $17.02 \pm 0.54 *$ & $17.13 \pm 0.63$ & $17.16 \pm 0.58$ \\
\hline Weight $[\mathrm{kg}]$ & $64.21 \pm 12.61$ & $64.31 \pm 12.63$ & $64.13 \pm 12.62$ & $70.59 \pm 11.70 *$ & $58.13 \pm 10.23 *$ \\
\hline High $[\mathrm{m}]$ & $1.71 \pm 0.09$ & $1.70 \pm 0.09$ & $1.71 \pm 0.09$ & $1.78 \pm 0.06 *$ & $1.64 \pm 0.06 *$ \\
\hline Waist $[\mathrm{cm}]$ & $72.10 \pm 8.70$ & $73.60 \pm 8.03 *$ & $70.79 \pm 9.05 *$ & $75.99 \pm 8.09 *$ & $68.39 \pm 7.58 *$ \\
\hline Hip $[\mathrm{cm}]$ & $93.98 \pm 7.18$ & $95.28 \pm 6.69 *$ & $92.85 \pm 7.42 *$ & $94.83 \pm 7.09 *$ & $93.17 \pm 7.19 *$ \\
\hline BMI $\left[\mathrm{kg} / \mathrm{m}^{2}\right]$ & $21.90 \pm 3.29$ & $22.08 \pm 3.23$ & $21.75 \pm 3.35$ & $22.36 \pm 3.21 *$ & $21.46 \pm 3.32 *$ \\
\hline WHtR & $0.42 \pm 0.05$ & $0.43 \pm 0.04 *$ & $0.41 \pm 0.05 *$ & $0.43 \pm 0.05 *$ & $0.42 \pm 0.04 *$ \\
\hline WHR & $1.03 \pm 0.17$ & $1.02 \pm 0.16$ & $1.03 \pm 0.18$ & $1.03 \pm 0.20$ & $1.01 \pm 0.13$ \\
\hline
\end{tabular}

${ }^{*} \mathrm{p}<0,05 a$ statistically significant difference, N - number of participants, BMI - Body Mass Index, WHtR -Waist to Height Ratio, WHR Waist to Hip Ratio. 
Most popular volume of energy drink packaging among high school students were 250-330 ml - $55.53 \%$ of the respondents usually buy such packages. Energy shots $(65-75 \mathrm{ml})$ usually reached $-14.65 \%$ of study group and $13.6 \%$ of respondents from rural areas and $15.6 \%$ of the urban areas. More students from rural areas drank beverages with a capacity of $500 \mathrm{ml}(14.1 \%)$ and $1000 \mathrm{ml}(5.1 \%)$ than from urban areas $(10.4 \%$ and $3.8 \%$ respectively). Beverages with a capacity of $1.5 \mathrm{I}$ and more frequently drank only students from rural areas (1.1\%). A group of residence did not differ significantly in terms of volume of packaging energy drink ( $p=0.8090)$.

Important differences pronounced in frequency of energy drinks consumption among the surveyed boys and girls $(p=0.0003)$. Examined girls energy drinks drank, mostly once a month $(21.89 \%)$ and boys less than once a week $(25.30 \%)$. Daily energy drink drank $1.58 \%$ of boys and less than $0.4 \%$ of girls. Boys and girls of the study population, significantly different also in the size of the packaging of energy drink which drank frequently $(p<0.0001)$. Most of the boys $(61.88 \%)$ drank beverages with a capacity of $250-330 \mathrm{ml}$ (girls $48.66 \%$ ). More often smallest packaging of energy drinks, with a capacity of 60$75 \mathrm{ml}$, selected girls $(20.86 \%)$ than boys $(8.91 \%)$. A half-liter $(15.84 \%)$ and liter $(7.43 \%)$ packaging of energy drinks, most often purchased study boys than girls (respectively girls: $8.02 \%$ and $1.07 \%$ ). None of the boys did not buy drinks with a capacity of $1.5 \mathrm{I}$, while that answer selected more than $1 \%$ of girls.

In the examined group among high school students, were statistically significant, but a weak correlations between selected parameters describing the frequency and amount of consumption energy drinks and overweight and obesity.

Weak positive correlations were noted between the frequency of consumption of energy drinks and such anthropometrics measurements like: waist circumference, body weight, BMI value and WHtR index (Figure 2) in the study group. Among the respondents from the rural region, observed poor positive, but statistically significant correlation between the frequency of consumption of energy drinks and selected parameters of nutritional status: waist circumference, body weight, BMI and WHR. Weak, statistically significant positive correlation was indicated in the interpretation and value of WHR index in subjects from urban regions (Figure 3 ). In the gender group, very weak positive correlation occurred in the case of frequency of consumption of energy drinks and interpretation of the indicator WHtR, WHR and BMI (Figure 4).

The amount of consumption of energy drinks, in study group, slightly increased waist circumference and weight. Very weak positive correlation was also in the case of interpretation of WHR and WHtR (Figure 5).In group of residence, positive weak correlation was recorded between the amount of consumption of energy drinks and waist circumference, WHR value and interpretation of the indicator WHtR in subjects from rural region of Southern Poland (Figure 6). In gender group, only in the case of girls there was weak positive correlation between the amount of the consumption of energy drinks and interpretation WHR (Figure 5).

\section{DISCUSSION}

Most of the surveyed high school students of the Southern Poland (almost 90\%) drink energy drinks. A study carried out among young people from the northern regions of the Poland, in the school year 2012/2013 showed $66.8 \%$ prevalence in the consumption of energy drinks. Significantly more often these beverages selected boys (74.6\%) than girls $(60.8 \%)$ [11], as in own study. Research conducted by Gaździńska et al. showed that energy drinks were more popular among young people living in the cities (17.7\%) than in the countryside - $9.1 \%$ [12], which is confirmed by the results of our study as well.

In the study was observed a weak association between consumption of energy drinks with overweight and obesity as well as type of abdominal

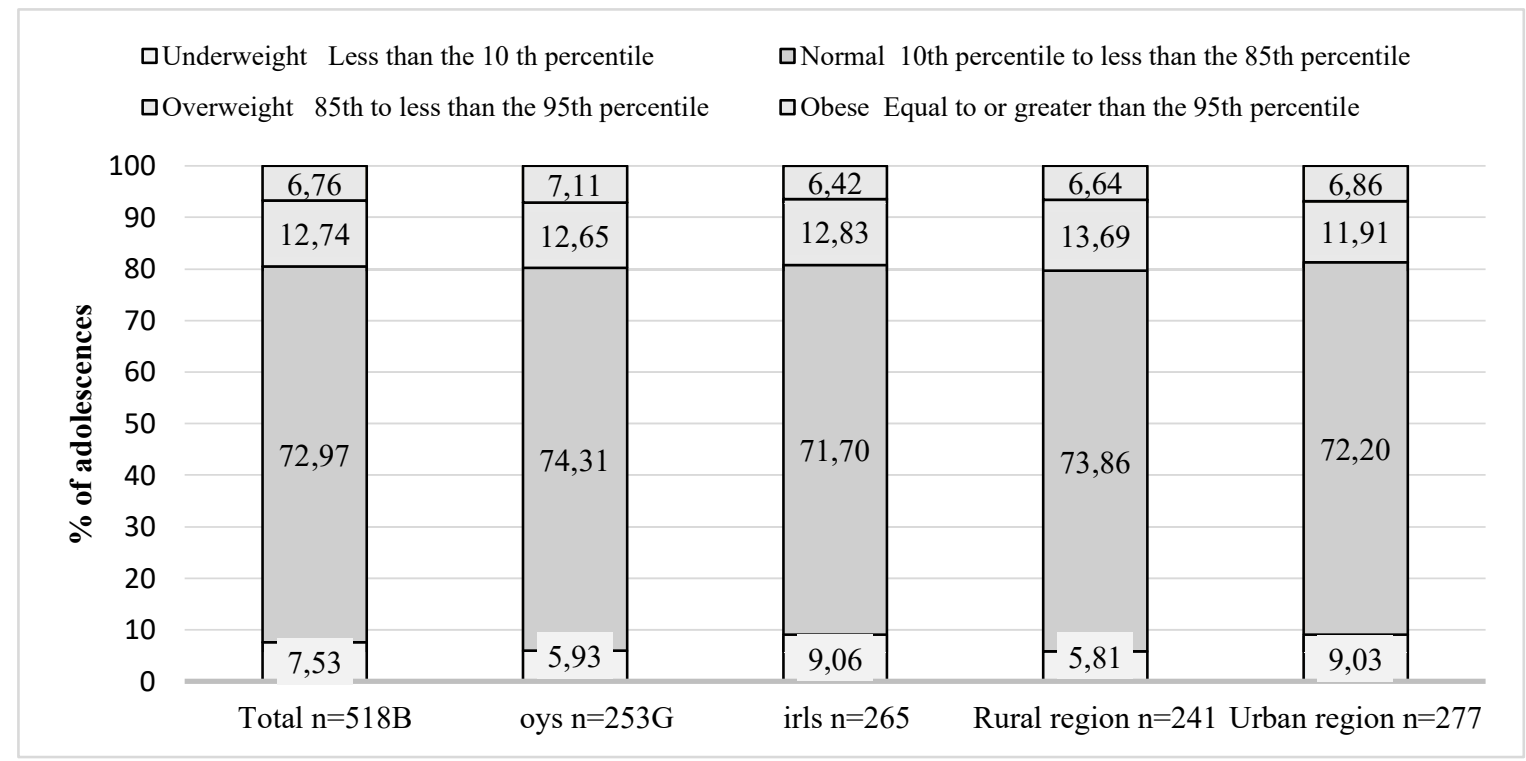

Figure 1. Evaluation of nutritional status according to the interpretation of BMI in the test group, takingintoaccountgender and place of residence. 
obesity. Positive, but weak statistically significant correlations related to the frequency and amount of consumption of energy drinks in the study group overall, and place of residence and gender were observed.

Consumption of energy drinks in other studies, with the declared frequency of once or several times a week was associated with obesity (OR = 0.87 vs overweight and normal weight). Frequent consumption of sugary drinks, sweetened coffee or tea, fruit drinks, milk, 100\% juice, and alcohol was significantly associated with higher consumption of both sports drinks and energy drinks [13]. Boys who consumed significantly more energy drinks also had significantly higher BMI $(r=0.33$; $p<0.05)$ and the thickness of folds of skin - fat $(r=0.46 ; p<0.05)$ in Łagowska studies [14]. Young people with excessive body mass consumed energy drinks 8.5 times higher compared to the other participants in the study done by Bajerska et. al.[15]. In previously own study, conducted with high school students from rural areas, boys, who significantly more likely reach for energy drinks, was found positive correlation between the frequency of drinking these beverages and the mean values and the interpretation of BMI $\left(r_{s}=\right.$ $0.4, p=0.0117$ ) [16].
Energy drinks are sugary beverages, and like other sugar soft drinks may be associated not only with obesity, but also with abdominal obesity. In the group of more than 2.700 teenagers aged 1216 , years increased consumption of sugary drinks was associated with significantly higher values of waist circumference in boys and girls group ( $p=$ 0.043 ) [17]. Children and adolescents consuming daily over $90 \mathrm{ml}$ of sweet beverages had almost 3-fold higher risk of developing metabolic syndrome $(\mathrm{OR}=3.20 ; 95 \% \mathrm{CI}=1.06-9.90)$, obesity (OR = $2.49 ; 95 \% \mathrm{CI}=1.00-6.53$ ) and hypertension (OR $=2.79 ; 95 \%$ CI $=1.02-7.64)$ [18].

Energy drinks, as test results of Larson et al. showed, have been linked also with behaviors that are associated with the development of overweight and obesity. Consumption of energy drinks was associated with less frequent breakfast consumption and at the same time, higher intake of sweetened carbonated beverages. Respondents also spent more time playing computer games, more often demonstrated their unhealthy behaviors related to weight control. Sleep problems and the use of psychoactive substances among men and women $(p<0.05)$ were reported in the groups consuming energy drinks $[19,20]$.

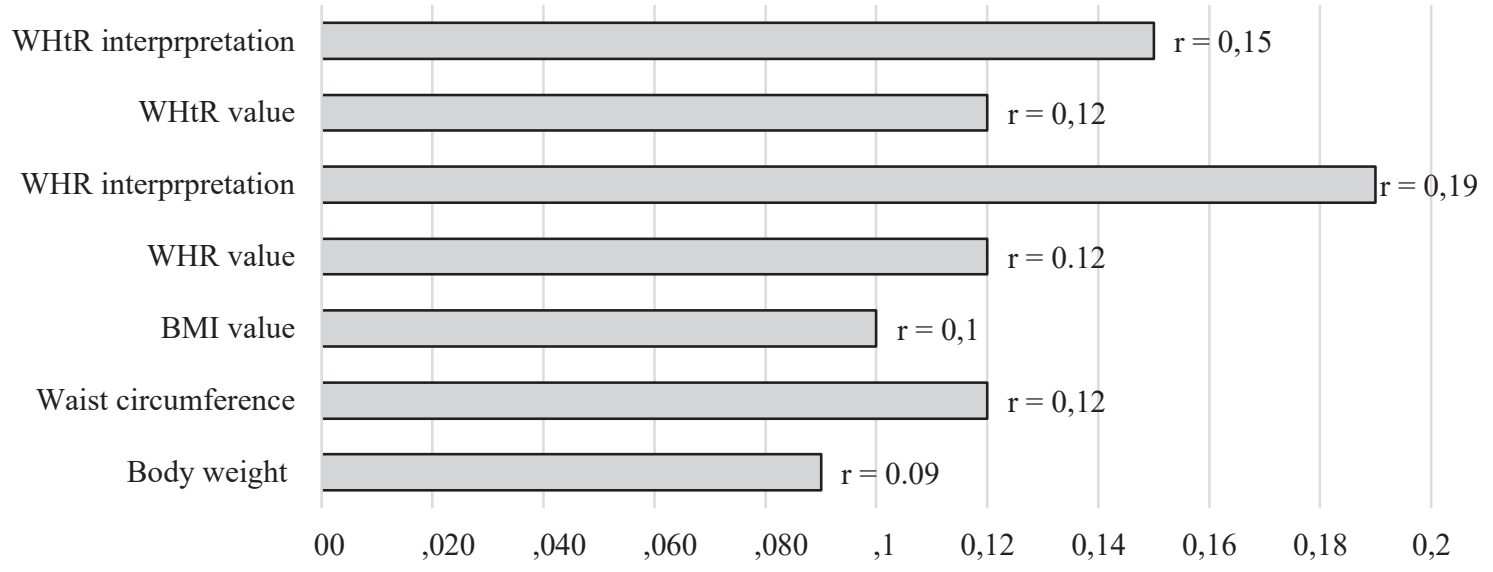

Figure 2. Significant correlation coefficients between frequency of energy drinks consumption and anthropometric measurements.

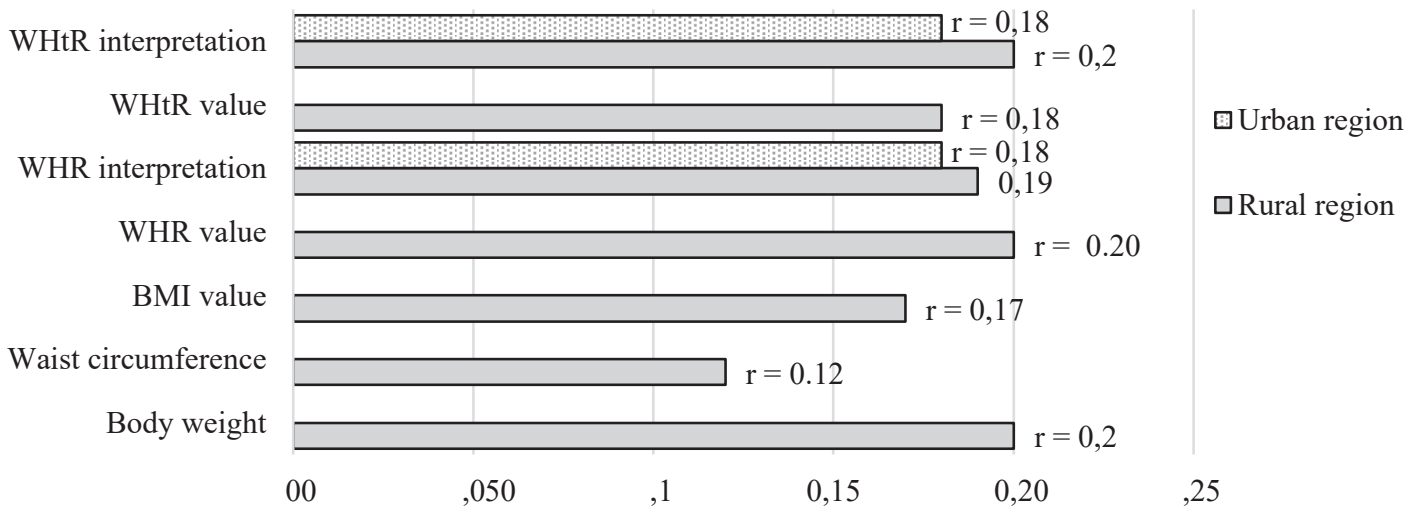

Figure 3. Significant correlation coefficients between frequency of energy drinks consumption and anthropometric measurements according to group place of residence. 


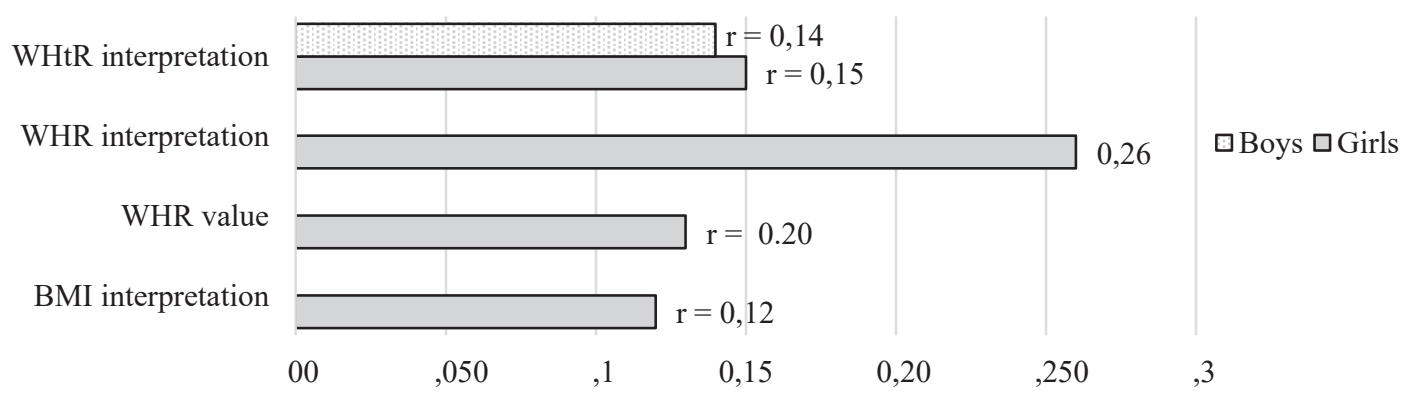

Figure 4. Significant correlation coefficients between frequency of energy drinks consumption and anthropometric measurements according to gender group.

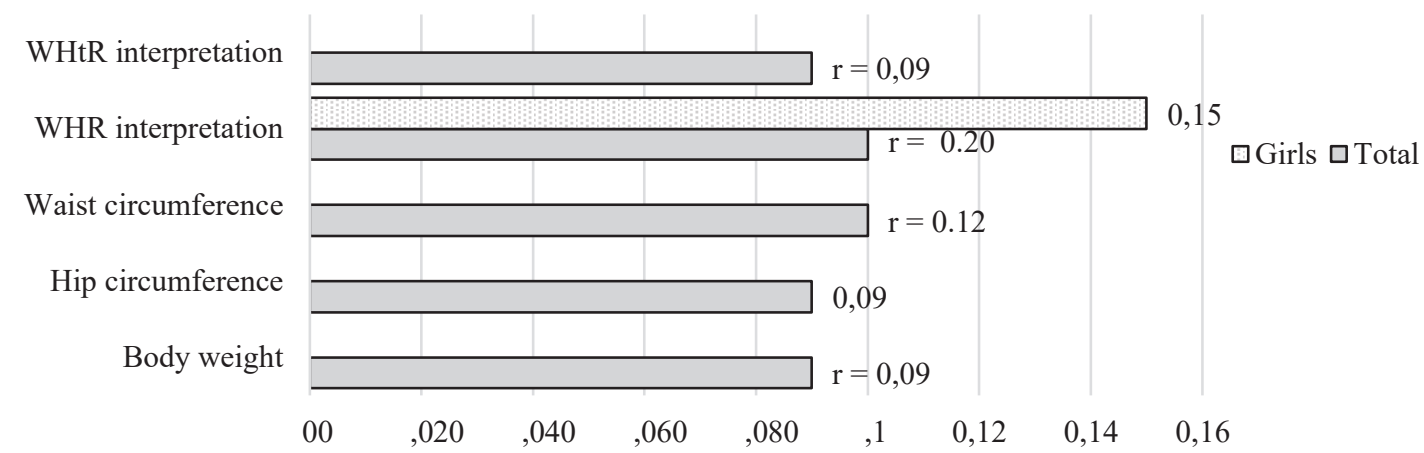

Figure 5. Significant correlation coefficients between frequency of energy drinks consumption and anthropometric measurements in total and gender group.

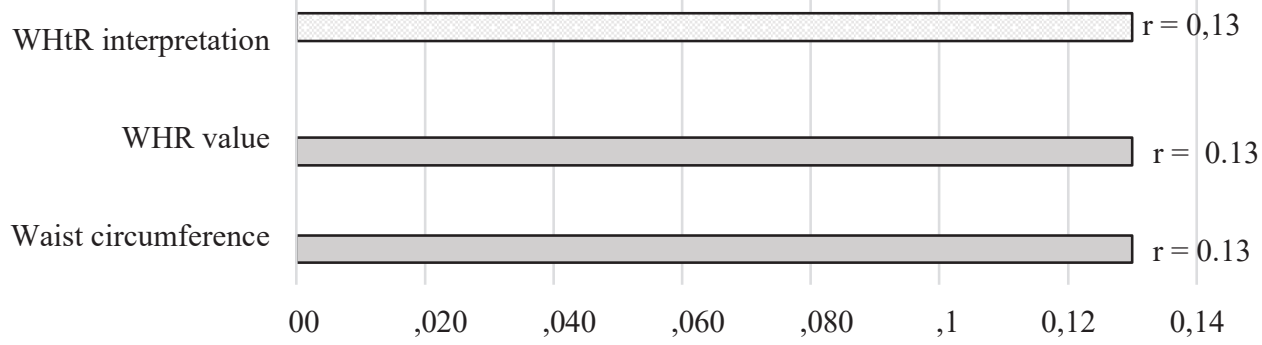

Figure 6. Significant correlation coefficients between frequency of energy drinks consumption and anthropometric measurements according to place of group residence.

\section{CONCLUSION}

The frequency and amount of consumption energy drinks, like other sweetened drinks, among adolescents is interlinked with overweight and obesity as well as type of abdominal obesity. 


\section{REFERENCES}

1. Breda JJ, Whiting SH, Encarnação R, Norberg $S$, Jones $R$, Reinap $M$. et al.[Internet] Energy drink consumption in Europe: a review of the risks, adverse health effects, and policy options to respond. Front Public Health. 2014; $2: 134$. [cited 2016 Jun 20]. Available from: doi:10.3389/fpubh.2014.00134.

2. Wierzejska R, Jarosz $M$. Napoje energety zujace a zdrowie - postepwiedzy. Med Wieku Rozw. 2011; 15(4):507-12.

3. Seifert SM, Schaechter JL, Hershorin ER, Lipshultz SE. Health effects of energy drinks on children, adolescents, and young adults. Pediatrics. 2011; 127(3):511-28.

4. Zucconi S, Volpato C, Adinolfi F, Gandini E, Gentile $E$, Loi A. et al.[Internet] External Scientific Report: Gathering consumption data on specific consumer groups of energy drinks. 2013 [cited 2016 Jun 23]. Available from: http://www.efsa.europa.eu/en/supporting/ pub/394e.htm.

5. Grembecka M, Lebiedzińska A, Mróz M, Szefer P. Ocenazawartościsacharozyi cukrówprostych w wybranychnapojachenergetyzujacych. Probl Hig Epidemiol. 2013; 94(2):339-41.

6. Harrington $\mathrm{S}$. The role of sugar-sweetened beverage consumption in adolescent obesity: a review of the literature. J Sch Nurs. 2008; 24(1):3-12.

7. Marks R. [Internet] Energy drinks: a potentially overlooked obesity correlate. Adv Obes Weight Manag Control. 2015; 2(4):00019 [cited 2016 Jun 30]. Available from: doi: 10.15406/ aowmc.2015.02.00019.

8. Poulos NS, Pasch KE. [Internet] Socio-demographic differences in energy drink consumption and reasons for consumption among US college students. Health Educ J2015; 4 [cited 2016 Jun 23]. Available from: doi: $10.1177 / 0017896915578299$.

9. Kułaga Z, Różdżyńska A, Palczewska I, Grajda A, Gurzkowska B, Napieralska E, et al. Siatkicentylowewysokości, masyciałaiwskaźni kamasyciaładzieciimłodzieży w Polsce - wynikibadania OLAF. Stand Med, Pediatr. 2010; 7:690-700.

10. Alberti KG, Zimmet PZ. Definition, diagnosis and classification of diabetes mellitus and its complications. Part 1: Diagnosis and classification of diabetes mellitus provisional report of a WHO Consultation. Diabetic Med. 1998;15(7):539-53.

11. Ng $M$, Fleming $T$, Robinson $M$, Thomson $B$, Graetz N, Margono C. et al. Global, regional, and nationalprevalence of overweight and obesity in children and adultsduring 19802013: a systematicanalysis for the Global Burden of Disease Study 2013. Lancet 2014; 384(9945): 766-81.

12. Gaździńska A. Suplementacja Składnika mimineralnymi, witaminamii napojamienergetyz ującymidietykandydatów do WyższejSzkołyO ficerskiejSiłPowietrznych. Żyw Człow Metab. 2007; 34(1/2):84-90.

13. Park S, Onufrak S, Blanck HM, Sherry B. Characteristics associated with consumption of sports and energy drinks among US adults: National Health Interview Survey, 2010. J Acad Nutr Diet.2013; 113(1):112-19.

14. Łagowska K, Woźniewicz M, Jeszka J. Porówn anienawykówżywieniowychmłodzieży z uwzglę dnieniempłciorazpoziomuaktywnościfizycznej. Rocz Panstw Zakl Hig. 2011; 62(3):335-42.

15. Bajerska J, Woźniewicz M, Jeszka J, Wierzejska E. Częstośćspożyciana pojówenergetyzujących, a aktywnośćfizycznaiwystępowanianadwagiio tyłościwśródmłodzieżylicealnej. Żywn Naukan Technol Jakość.2009; 4(63):211-17.

16. Błaszczyk E, Piórecka B, Jagielski P, SchlegelZawadzka M. Konsumpcja na pojów energetyzuj ącychizachowania z niązwiązanewśródm łodzieżywiejskiej. Probl Hig Epidemiol.2013; 94(4):815-19.

17. Chan TF, Lin WT, Huang $\mathrm{HL}$, Lee CY, Wu PW, Chiu YW.et al. Consumption of sugar-sweetened beverages is associated with components of the metabolic syndrome in adolescents. Nutrients. 2014; 6(5):2088-2103.

18. Mirmiran P, Yuzbashian E, Asghari G, Hosseinpour-Niazi S, Azizi F. [Internet] Consumption of sugar sweetened beverage is associated with incidence of metabolic syndrome in Tehranian children and adolescents. Nutr Metab. 2015; 12:25 [cited 2016 Jun 20]. Available from: doi:10.1186/s12986-015-0021-6.

19. Larson N, De Wolfe J, Story M, Neumark-Sztainer D. Adolescent consumption of sports and energy drinks: linkages to higher physical activity, unhealthy beverage patterns, cigarette smoking, and screen media use. J Nutr Educ Behav.2014; 46(3):181-87.

20. Larson N, Laska MN, Story M, Neumark-Sztainer D. Sports and energy drink consumption are linked to health-risk behaviors among young adults. Public Health Nutr.2015; 16:1-10. 